\begin{tabular}{c} 
Volume and Issues Obtainable at Center for Sustainability Research and Consultancy \\
Journal of Accounting and Finance in Emerging Economies \\
ISSN: 2519-0318 ISSN (E) 2518-8488 \\
Volume 6: Issue 3 September 2020 \\
JSRᄃ \\
Journal homepage: www.publishing.globalcsrc.org/jafee \\
\hline
\end{tabular}

\title{
Financial Literacy among SMEs' Owners in Sumatera, Indonesia: The Role of Parents' Motivation and Experience
}

\begin{tabular}{|c|c|}
\hline ulty of Ecor & $\begin{array}{l}\text { Rika Desiyanti, }{ }^{2} \text { Aza Azlina Md Kassim } \\
\text { iness Bung Hatta University, Indonesia: rikadesiyanti@b b } \\
\text { iness and Accountancy, Universiti Selangor, Indonesia }\end{array}$ \\
\hline ARTICLE DETAILS & \multirow{5}{*}{$\begin{array}{l}\text { ABSTRACT } \\
\text { Financial literacy is the skill to conduct personal and also business finance. } \\
\text { Financial literacy shows information and reasoned both for the economy and } \\
\text { finance. Financial literacy is able to apply and regulate financial literacy that } \\
\text { affects wellbeing. } \\
\text { In } 2013 \text {, the financial services authority (OJK) has conducted a financial } \\
\text { survey and the result indicated that only } 21.8 \% \text { of people understand finance } \\
\text { and in 2016, the percentage has increased from about } 8 \% \text { to } 29.66 \text {. } \\
\text { Lacking strength of financial literacy gives low effect on financial decisions, } \\
\text { including less saving, opting for more leverage, and involved in unprofitable } \\
\text { investments. This paper a particular goal to analyze the influence of parental } \\
\text { motivation and experience on financial literacy. Research sample is SMEs' } \\
\text { Owners in Sumatra, Indonesia, have been sent questionnaires. Based on a } \\
\text { sample of } 60 \text { respondents it can be concluded that parents' motivation affected } \\
\text { their financial literacy. Nevertheless, financial experience by the parents does } \\
\text { not affect financial literacy. }\end{array}$} \\
\hline & \\
\hline $\begin{array}{l}\text { Revised format: August } 2020 \\
\text { Available Online: September } \\
2020\end{array}$ & \\
\hline $\begin{array}{l}\text { Keywords } \\
\text { Parents, motive } \\
\text { experience, finan }\end{array}$ & \\
\hline $\begin{array}{l}\text { JEL Classific } \\
M 40, M 41\end{array}$ & \\
\hline
\end{tabular}

\section{OPEN ACCESS}

(C) 2020 The authors, under a Creative Commons Attribution-NonCommercial 4.0

Corresponding author's email address: rikadesiyanti@bunghatta.ac.id

Recommended citation: Desiyanti, R. \& Kassim, A. A. M. (2020). Financial Literacy among SMEs' Owners in Sumatera, Indonesia: The Role of Parents' Motivation and Experience. Journal of Accounting and Finance in Emerging Economies, 6(3), 821-829

\section{Introduction}

Financial literacy issue gain wide attention in to day. Financial literacy and the awareness of saving have become a priority in the county's economic and social policy. Financial literacy regulates financial problems at both personal and business levels. Boehnke et al. (2018) state that knowledge and capabilities in financial management are among the important aspects of life. Therefore, financial literacy regulates financial problems and the implementation of financial activities at the individual and business level. Each person must have knowledge and skills in managing their assets. Financial literacy helps poor people to avoid financial problems. Financial knowledge and skills are essential so that people can avoid making inaccurate financial decisions. Financial literacy allows people to recognize, understand, and apply their financial basis in daily life to be successful. Financial literacy direct to a source for a person's ability to make good economic and financial decisions for the best of his or her own life (Mandell, 2008a; Rosacker \& Rosacker, 2016).

Effective financial literacy may help to avoid financial problems because people often encounter a situation where they have to sacrifice their interests. Financial literacy influences matters related to financial planning, spending, 
credit card usage, existing savings, investments, financial management, and making financial decisions. Financial literacy is fractions of the basic human necessary. Financial literacy is crucial in managing one's financial sources. Knowledge of financial literacy is currently increasing in demand. It is a good sign as it helps to create a society that has good financial knowledge. Financial management make good the life of the community itself and it brings a positive influence on the economy.

Financial literacy is important in everyone's life (Grohmann \& Menkhoff, 2015). Financial literacy is a process of building the ability to understand the products as well as financial concepts through information, instruction, and suggestion to develop expert and self-consciousness and awareness of financial risks. Know and understandable finances is important for businessmen, mainly for the SMEs' owners. SMEs support the economy of the country.

SMEs are considered as an important component within the business sector. Most of the SMEs in Indonesia remained during the economic crisis. SMEs strengthen the economy of Indonesia. SMEs can survive as compared to other large businesses. SMEs have an important role in creating job opportunities for the community. SMEs' development is one of the government initiatives to enhance the economy of the community.

A survey done by the Ministry of Cooperatives proves that SMEs can thrive in Indonesia. Indonesia experienced a dreadful monetary crisis in 1998, and the sector that remains was the small and medium business sectors (SMEs). The resilience of SMEs during the crisis indicates that SMEs are an important asset for the sustainability of the country's economy.

However, a national survey conducted in 2013 showed that financial literacy among the respondents in Indonesia was $21.8 \%$. Even in 2016, the level of financial literacy has increased to more than $8 \%$. It shows a worrying sign since financial literacy is essential in everyone's life especially for those who run the business. Insufficient financial literacy leads to ineffective financial decision makings and financial difficulties. Previous studies indicated that parents' motivation and parents' experience particularly the financial education and literation important for parents (Norvilitis \& MacLean, 2010; Lusardi et al., 2010). It contributes for skills and knowledge in the children's financial management and it leads to their financial attitude and behavior when they grow up. Parents may give examples of how to spend money wisely.

Their child's financial education is led by parental experience and motivation. In other wordsTheir children's financial knowledge is derived from their parents' experiences. Van Campenhout (2015) suggests that it is important for parents in building their children's financial independence. This can be done through modelling the norms on finance, teaching the concept of financial or by giving chance to their children to manage their own money. All of these activities will facilitate the children in experiencing financial knowledge, and in the future, will give them the ability in having good financial literacy as well as making good financial decision. (Norvilitis \& MacLean, 2010; Lusardi et al., 2010).

Experiencing children in financial activities requires both theories and practices. Parents should give good examples in showing how to manage the money well. Children with sufficient education and experiences of financial from their parents tend to have better finance and higher grade of financial literacy.

\section{Literature Review and Hypotheses Development \\ 2.1. Financial Literacy}

Financial literacy refers to an individual's ability to manage or use money (Lusardi et al., 2008; Berry, et al., 2018). Financial literacy is highly related to habits that are influenced by various external factors. Huston (2010) states that financial knowledge also part of financial literacy, but it is not able to describe one's financial literacy. Good decision making is influenced by sufficient financial literacy. Financial literacy education has become a necessity for everyone particularly in facing the challenges and uncertainty in the economy nowadays.

Financial literacy helps to prevent financial problems. Mismanagement of financial resources can bring disasters to an individual or a business. Effective financial management should be backed by good financial literacy to improve 
social welfare. High saving and a good investment are due to proper financial management. Financial literacy is crucial in managing financial sources. Currently, exposure to financial literacy is needed to create a social community that has good financial knowledge. Financial knowledge is very useful in making accurate and wise financial decisions. Good financial management will be able to protect the community from having financial difficulties or bankruptcy. Financial literacy has a comprehensive meaning towards understanding in financial management. As revealed by Vitt et al. (2000), and Jorgensen (2007) financial literacy education provides able to read, analyze, manage, implement, and communicate about conditions and decisions of finance.

Children's socialization process is mainly affected by their parents. Therefore parents should be able to educate and motivate their children in developing knowledge, values and beliefs in all aspects of life. Jorgensen (2007) and Rapih (2016) describe how the environment could give important contribution to someone's future life. Daily conversation with the parents and continuou experiences related to financial activities and events will indirectly increase children's financial literacy a well as build their values and attitudes about money. (Rapih, 2016; Allen, 2003).

The formation of attitudes as well as the cultivation of the values of life in the family is very important. The parent became the first communication medium for children and a school is a place where they can interact with friends. According to Jorgensen (2007), describes social learning theory as the influence of one's environment that may shape an individual's attitude and behavior. Such behavior derived from the home environment. Sabri et al. (2010) say that someone who has been exposed about financial experience in his childhood life, will have a positive influence on his/her financial literacy. The parents' roles in financial literacy provide their children with knowledge and experience of finance.

Moreover, educational aspect which is derived from family will strongly become a fundamental understanding for the children in develop their good attitude and behaviour in utilizing their money. It is an important skill since they have to manage their finance well, trained to independently make payments for their needs, have good plans for managing their pocket money. students, where their finances are still given by their parents will make them having higher knowledge, value and attitudes of financial behaviour. Parent have a necessary function in the process of financial socialization of their children (Cude et al., 2006; Jorgensen, 2007).

Parents can be relied upon to provide enough financial literacy knowledge to their children. The presence of good financial education in families will affect children's literacy. India's life of living together in a family shows that participating in financial literacy programs may increase the parent financial decision making (Agarwal et al., 2013; Shim \& Shin 2017). According to Mandell (2008), the involvement of parents has an important influence in education, motivation, and their children's understanding of financial matters. The children can manage finances from parents' home. The results of the survey show that $58.3 \%$ of the children ability came from their upbringing by the parents, $19.5 \%$ are from education in schools, and $17.6 \%$ learn from their experiences. This is supported by research conducted by Shim and Shin (2017) that explains families and parents' socialization influence the children learning process on financial management (through direct participation or observation) given by the parents.

The involvement of parents in financial education such as having discussions with children about financial issues is very essential for good educate of financial literacy among family members. Through educated children may have great attitudes and values that they get from their parents. Jorgensen (2007) states that students with sufficient education from their parents in control money well, will better in finance than those students who do not have any experience about financial managing from their parents. Nowadays, Financial literacy education is an issue and a major concern in most countries of the world. This is because financial management awareness will increase.

Adult education about financial literacy has become a major concern in most countries in the world. There is an increase in the awareness of financial management and its influence on any individual in the society. In Indonesia, financial literacy education has been emphasized by the OJK, Bank Indonesia, the Ministry of Education and Culture, and others. They believe that financial literacy education should be taught at the early stage since it gives an impact on individual financial decision making when they grow up.

Sufficient financial literacy will lead to healthy financial management. Research conducted by Chen and Volpe (1998) 
found that youths with a minus of financial literacy tend to make error in financial decisions. The need for financial literacy education is necessary for everyone's future. With such literacy, every individual can manage their finances, understand how the system in the economy works, think economy problems critically, feel a responsibility, understand basic economic concepts (production, distribution, consumption), involved in economic decision-making, provide logical reason about current issues that give impact to their lives, and ready to participate in the activity of economic production to prepare for their future careers (Clarke et al., 2005).

Education on financial literacy should be a continuous commitment and active participation by various parties. The parents become the first for children to socialize with friends in their environment. It may be effective to internalize the value of financial literacy education for the child. The process of cultivation of the values of financial literacy education requires a long and continuous process. There must be an interrelation between the lessons taught in the home and at school.

Nowadays, teaching about financial literacy to children falls on the parents, but research shows that most parents do not have the skills to teach financial literacy to their children. Parents should be the first source for them to learn various lessons including financial literacy education. Unfortunately, parents think their children can understand those lessons, particularly on financial matters when they reach 18 years old (Sabri et al., 2010). Danes (1994) found that parents are the main agent in the process of acquiring knowledge about financial literacy for their children, but their roles have not been maximized.

Parenting pattern teaches and demonstrates the concept of finance where knowledge about financial literacy must be exposed from children to adolescents. Good parenting patterns involve teaching and demonstrating the concepts of finance from an early age to adolescence (Danes, 1994). Direct influence from parents by giving lessons in keeping expenditures can cause an enhancement of financial knowledge, attitudes, values, and behaviors to money management (Allen, 2003).

Parents who rarely involve their children in decision-making activities will make their children less critical in dealing with problems that arise around them. The simple step is to involve them in making a-financial decision on matters associated with them. The child should be given the opportunities for discussion about the allocation and determination of their financial problems. Critical thinking will grow with dialogue between parents and children in financial decisions. Dialogue and discussion about the allocation and determination of their financial matters. The existence of a dialogue between parents and children in financial decision making is useful for cultivating their critical thinking.

Social learning theories explains that childrens posses their experiences about finance through observing, getting reinforcements, both positives and negatives, practising, participating, getting instruction, getting motivation from their parents.

\subsection{Parents' Motivation}

Widayati (2014) and Rapih (2016) state that several ways in teaching and experiencing children about financial skills are by train them about basic finance activities such as saving, making their own payment independently, managing their pocket money, having part-time jobs and giving donation and making their investment.

Parents' motivation is important as it may influence the children's financial literacy. Students who received motivation from their parents in their financial management education are more likely to get higher scores in attitudes, behaviors of financial literacy, (Jorgensen, 2007).

Parents are the most important entity for children to learn and get experience particularly in financial education (Cude et al., 2006). Children tend to follow the examples taught by their parents. Through parents' education, it may influence the children's attitude and value system. By giving them motivation and opportunity in deciding and get involved in financial decision making, it may give them experience and exposures. 


\subsection{Parents' Experiences}

Parental involvement in financial literacy produces knowledge and experience in financial management. When children become adults, they will become smart consumers and financial users (Bowen, 2002). Introducing a child to financial institutions can be in the form of saving money in the bank. Children are taught not to withdraw their money easily. They will have a better ability to resist any urge to fulfill their desires. In addition, children will get used to set aside their money to be kept in the bank. Previous studies show that kids can learn about financial matters from their elderly through deliberate instructions, participation, and implementation through observations (Clarke, 2005).

\section{Hypothesis Development}

The literature on the correlate between parents' motivation and parents' experience of financial literacy leads to hypothesis development.

\subsection{Parents' Motivation and Financial Literacy}

The involvement of highly educated parents in providing motivation will increase financial literacy (Santrock, 2008). It affects the children's exposure, knowledge, and skills in finance with various activities that involve financial decision making created by the parents. There is a correlation between parents' motivation and financial literacy (Firmansyah, 2014). Education and motivation from parents have an impact on financial literacy (Lusardi et al, 2010; Ansong \& Gyensare, 2012; Cole, et al., 2008; Rudeloff, 2019; Micek, 2020). The preceding argument leads to the following hypothesis:

H1: There is a positive influence of parents' motivation on financial literacy.

\subsection{Parents' Experience and Financial Literacy}

Everyone requires knowledge and skills for personal financial decision makings. Insufficient knowledge of financial management will create a negative impact on anyone's life. Financial management knowledge is easy to be obtained from their parents' experience. Jorgensen (2007) explained that testing the influence of financial activities modelling from parents with good financial literacy to their children since the beginning, should be done. Moreover he said that testing about modelling is commonly done. In accordance to that, this research is also doing testing about the influence of parents' financial modelling to discover how far it is affected the process of their children's financial socialization.

Sabri et al. (2010) investigated the influence of personality, parents' motivation, and parents' experience on financial literacy among students. Students who had no experience communicating and discussing financial matters with their parents. (Gudmondson \& Danes, 2011; OECD 2017) describes people discuss money issues with their parents and friends. The parents could provide continuous great advice will bring a good financial impact on the children. The children who oftenly having discussion about financial things with their parents will associate a higher score in financial literacy. Hogan et al. (2010) stated that people's work experience correlates with financial literacy. People must have long working experience, knowledge, and financial skills in their life. The parents' experience in managing they are financial will influence the children's financial literacy. Based on this assumption, the next hypothesis is:

$\mathrm{H} 2$ : There is a positive impact of parents' experience on financial literacy

\subsection{Research Framework}

The research framework on the effect of parent motivation and parent experience on financial literacy is illustrated in Figure 1.

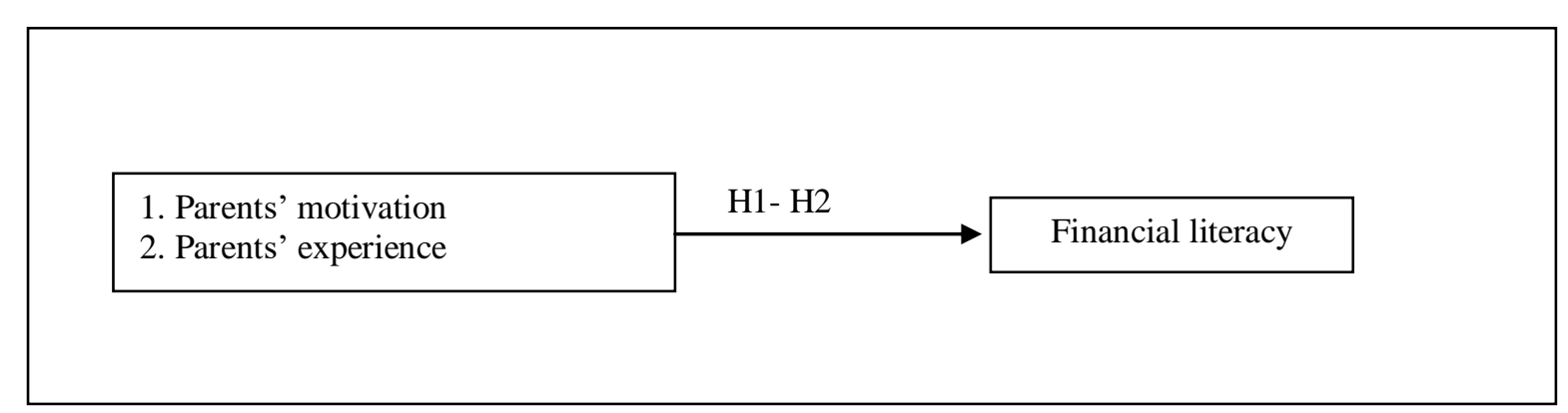




\section{Figure 1. Research Framework}

\section{Methodology}

\subsection{Population and Sample}

All small-medium enterprises in Sumatera, Indonesia are the population of this study. The samples then, are taken from this population. According to Sekaran (2018), the sample size is 20 times the number of variables in the study. There are three main variables in the study i.e., parents' motivation, parents' experience, and also financial literacy. The sampling technique is a convenience sampling design. A total of 60 returned questionnaires were received.

\subsection{Dependent Variable - Financial Literacy}

Lusardi and Mitchell (2014) present financial literacy in the form of true and false questions. Financial literacy is measuring by calculating numbers of correct answers then divided by the number of all correct answers by the respondents. Respondents' answers are categorized into 3 groups (Sabri et al., 2010; Chen \& Volpe, 1998; Nababan \& Sadalia, 2012; Rahayu \& Musdholifah, 2017; Yushita 2017) namely:

a. Group 1 (60\% of SMEs' owners have lower gain, skill, behavior, and attitude of financial).

b. Group 2 (61\%-79\% of SMEs' owners have lower gain, skill, behavior, and attitude of financial).

c. Group 3 (> 80\% of SMEs' owners have lower gain, skill, behavior, and attitude of financial).

\subsection{Independent variable -Parent Motivation and Parent Experience}

The independent variable is represented by parents' motivation and parents' experience. According to OECD (2017) and Widayati (2014), the financial knowledge and literacy are influenced by parents' motivation and parents' experience which are measured by using five points Likert scale $(1=$ strongly disagree, $2=$ disagree $3=$ neutral, $4=$ agree and also $5=$ strongly agree).

\section{Result}

The result in this study the descriptive and regression as follow:

Table 4 - Descriptive Parents' Motivation, Experience, and Financial Literacy

\begin{tabular}{|c|c|c|c|}
\hline Variables & Mean & SD & Range \\
\hline Parent motivation & & & $1-5$ \\
\hline I have been motivated by my parents to get involved in family business & 3.76 & 1.05 & \\
\hline $\begin{array}{l}\text { I and my family members have been motivated by my parent in having } \\
\text { financial knowledge. }\end{array}$ & 3.31 & 1.11 & \\
\hline My parents took parts in the process of my financial socialization & 3.67 & 0.96 & \\
\hline $\begin{array}{l}\text { financial literacy has been experienced and motivated to me by my parents } \\
\text { since my early childhood }\end{array}$ & 3.67 & 0.84 & \\
\hline All of the children are got involved in financial decision making, by parents & 3.57 & 0.94 & \\
\hline Parent experience & & & $1-5$ \\
\hline family is the first instituion that tought about financial literacy & 3.65 & 0.96 & \\
\hline my parents experiences is my role models for my business & 3.52 & 0.93 & \\
\hline $\begin{array}{l}\text { I frequently discuss with my parents about effective ways in slending my own } \\
\text { money. }\end{array}$ & 3.57 & 1.01 & \\
\hline My parents are my role model in managing money & 3.73 & 0.91 & \\
\hline my parents experienced high financial activities and moments. & 3.50 & 1.01 & \\
\hline $\begin{array}{l}\text { I can differenciate between needs and desires since my parents educate me } \\
\text { about that }\end{array}$ & 3.93 & 0.98 & \\
\hline Financial literacy & & & 1 and 0 \\
\hline Savings Interest is exceeding the deposit interest & 0.35 & 0.48 & \\
\hline Credit card holders can shop as freely as possible & 0.26 & 0,44 & \\
\hline credit cards have the lowest financial costs & 0.30 & 0.46 & \\
\hline Insurance is the best investment & 0.56 & 0.50 & \\
\hline all profitable investments & 0.43 & 0.49 & \\
\hline Investing can be done by borrowing & 0.57 & 049 & \\
\hline
\end{tabular}


Table 5 - Regression Model

\begin{tabular}{llll}
\hline Predictors & $\mathrm{B}$ & $\mathrm{SE}$ & $\mathrm{t}$-statistics \\
\hline Constant & -0.01 & 0.152 & $-0.008^{* *}$ \\
Parent motivation & 0.095 & 0.036 & $3.453^{* * *}$ \\
Parent Experience & 0.051 & 0.040 & 1.418 \\
& & & \\
R square $\left(\mathrm{R}^{2}\right)$ & & 0.311 & \\
Adjusted R-squared & & 0.287 & \\
F statistic & & 12.891 & \\
Significance F & & 0.000 & \\
\hline
\end{tabular}

a. Dependent Variable: financial literacy

$* * *, * *, *$ indicates regression analysis significant at $1 \%, 5 \%, 10 \%$ respectively

It shows that out of two independent variables, parents' motivation have a positive relationship to financial literacy at $5 \%$ significant level. Thus, hypothesis 1 is accepted. However, the parents' experience has no significant relationship to financial literacy. Thus, hypothesis 2 is not acceptable. This study fails to find any influence between parents' experience and financial literacy as the p-value is greater than $5 \%$.

\section{Discussion and Conclusion}

This study aims to discover the impact of parents' motivation and parents' experience on financial literacy. Results of analysis of 60 SME owners' answers, revealed an interesting facts. The results show that parents' motivation is one of important aspects in increasing financial literacy. For most of SME owners, parent' motivation become an essential factor in making them financially literate. This is also happened because their parents laso trained them through interactive discussion and activities about finance at their home. Related to this, Mandell and Klein (2007) found that people who come from better financial resources families, as well as have good motivation from their parents, are considerably more financially literate than those who come from less well-off families, thereby aggravating the discrapancy of economic level of welfare among families.

The result of this study also found that people that having experience in discussing financial with their parents or families members, are have relation to their financial literacy. The parents can help their shildren to build their financial skill and knowledge by giving their children motivation and being role models for their children while giving them direct experiences. Direct and explicit teaching and demontrating the concept of finance can affect their chidren's financial literacy from early stage. Unfortunately, it is found that parents' experiences which were transferred to their children do not have necessary contribution to their financial literacy. It is important for the parents to realize the best moments for their children to get involved in various financial activities so that they can get the best opportunity and take the advantages through learning experiences.

This study proposes that SMEs' owners should manage their finances with better understanding and skills. It may help to maintain the sustainability of business with effective financial management. The government supports to increase the level of financial literacy by issuing several policies in the fields of finance and financial products. For the financial services, it is necessary for more intensive authority in propagating literacy programs to the community. Furthermore, the academicians from higher learning institutions should assist the communities and SMEs owners to be literate and familiar with the financial issues. Besides, the study contributes to the literature on financial literacy. In addition, the study provides the essentials of having proper financial literacy among SMEs' owners and strengthening the roles of parents in giving experience and exposures in financial management.

\section{References}

Agarwal, S., Driscoll, J. C., \& Laibson, D.I. (2013). Optimal mortgage refinancing: a closed-form solution. J. Money, Credit Banking, 45(4), 591-622.

Allen, N. (2003). Organizational commitment in the military: A discussion of theory and practice. Military Psychology, 15, 237-253.

Ansong, A., \& Gyensare, M. A. (2012). Determinants of university working-students' financial literacy at the University of Cape Coast, Ghana. International Journal of Business and Management, 7(9), 126-133. 
Berry, J., Karlan, D., Pradhan, M. (2018). The impact of financial education for youth in Ghana. World Development, 102, 71-89.

Boehnke, M., Pokharel, S., Nyberg, E., \& Clark, T. (2018). Financial education for radiology residents: Significant improvement in measured financial literacy after a targeted intervention. Journal of the American College of Radiology, 15(1), 97-99.e1.

Bowen, C, F, (2002). Financial Knowledge Of Teens And Their Parents Cathy Faulcon Financial Counseling and Planning Volume 13(2)

Chen, H., \& Volpe, R. P. (1998) An analysis of financial literacy among college students. Financial Services Review, 7(1), 107-128.

Clarke, M. D., Heaton, M. B., Israelsen, C. L., \& Eggett, D. L. (2005). The acquisition of family financial roles and responsibilities. Family and Consumer Sciences Research Journal, 33, 321-340.

Cole, S., Sampson, T., \& Zia, B. (2008). Money or knowledge? What drives the demand for financial services in developing countries? Harvard Business School Working Paper, No. 09-117

Cude, B. J., Lawrence, F. C., Lyons, A. C. (2006). College students and financial literacy: What they know and what we need to learn. Eastern Family Economics and Resource Management Association 2006 Conference

Danes, (1994). Involvement with language and in language. Journal of Pragmatics, 22, pp 251-264.

Firmansyah, D. (2014). The influence of family backgrounds toward student saving behavior: a survey of college students in Jabodetabek. International Journal Of Scientific And Research Publication, Vol 1, Issue 1, pp 2250-3153.

Grohmann, A., Kouwenberg, R., \& Menkhoff, L. (2015). Childhood roots of financial literacy. Journal of Economic Psychology, 51 (September), 114-133. doi.org/10.1016/j.joep.2015.09.002.

Gudmondson, C. G. \& Danes, S. M. (2011). Family financial socialization: Theory and critical review. Journal of Family and Economic Issues, 32(4), 644-667.

Hogan, M., Foreman, K., Naghavi, M., Ahn, S., Wang, M., \& Makela, S. (2010). Maternal mortality for 181 countries, 1980e2008: a systematic analysis of progress towards millennium development goal 5. The Lancet, 375, 1609e1623, $\quad$ Retrieved 25.01.12, from. http://www.sciencedirect.com/science/article/pii/S0140673610605181.

Huston, J. S. (2010). Measuring financial literacy. The Journal Of Consumer Affairs, pp 296- 316.

Jorgensen, B. L. (2007). Financial literacy of college students: Parental and peer influences. Thesis

Lusardi, A., Mitchell, O. S. \&Curto, V. (2010). Financial literacy among the young. Journal of Consumer Affairs, 44(2), 358-380.

Lusardi, Annamaria \& Olivia S. Mitchell (2008). Planning and financial literacy: How do women fare? American Economic Review, 98(2), 413-417.

Lusardi, A., \& Mitchell, O. S. (2014). The economic importance of financial literacy: Theory and evidence. Journal of Economic Literature, 52(1), 5-44. http://doi.org/10.1016/j.sbspro.2015.01.229

Mandell, L., (2008)a. The financial literacy of young American adults: Results of the 2008 national jump-start coalition survey of high school seniors and college students. http://www.jumpstart.org/assets/files/2008SurveyBook. Acces 2 Mei 2018.

Mandell, L. (2008)b. Chapter 10 Financial Literacy of High School Students J.J. Xiao, (ed.), Handbook of Consumer Finance Research, Department of Finance, State University of New York at Buffalo, 375 Jacobs Hall, University at Buffalo, Buffalo, NY 14260-4000, USA, Springer.

Mandell, L. \& Klein, L. S. (2007). Motivation and financial literacy. Financial Services Review, 16, $105-116$.

Micek, B. (2020). Digitalcommons @ university of nebraska - lincoln young , dumb , and broke : how family communication affects financial literacy.

Nababan, D., \& Sadalia, I. (2012). Analisis personal financial literacy dan financial behavior mahasiswa strata 1 fakultas ekonomi universitas Sumatera utara. http://repository.usu.ac.id/handle/123456789/34557. Acces 3 February 2018

Norvilitis, J. M. \& MacLean, M. G. (2010). The role of parents in college students' financial behaviors and attitudes. Journal of Economic Psychology, 31(1), 55-63.

OECD (2017). Students experience with money and their performance in financial literacy, PSA 2015 Result, (Volume IV), Students' financial literacy

Rapih, S. (2016). Pendidikan literacy keuangan pada anak: mengapa dan bagaimana? Scholaria, 6(2), Mei 2016, 14-28 
Rahayu, A. P., Musdholifah (2017). Pengaruh literasi keuangan terhadap kinerja dan keberlanjutan umkm di kota Surabaya. Jurnal Ilmu Manajemen, 5(3), Jurusan Manajemen Fakultas Ekonomi Universitas Negeri Surabaya.

Rosacker, K. M., \& Rosacker, R. E. (2016). An exploratory study of financial literacy training for accounting and business majors. International Journal of Management Education, 14(1), 1-7. http://doi.org/10.1016/j.ijme.2015.11.002.

Rudeloff, M. (2019). The influence of informal learning opportunities on adolescents' financial literacy. Empirical Research in Vocational Education and Training, 11(1). https://doi.org/10.1186/s40461-019-0086-y

Sabri, M. F., MacDonald., Hira, T. K. \& Masud, J. (2010). Childhood consumer experience and the financial literacy of college students in Malaysia. Family \& Consumer Sciences Research Journal, 38(4), June 2010 455-467, DOI: $10.1111 / \mathrm{j} .1552-3934.2010 .00038 . x$

Santrock, J. W. (2008). Psikologi Pendidikan. Jakarta: Prenada Media Group

Sekaran, U. (2018). Research Methods for Business: a skill-building approach, 7th Edition, Wiley.

Shim, Y. and Shin, D.H. (2017). Analyzing china's fintech industry from the perspective factor network theory. Telecommunications Policy, 40(2-3), 168-181.

Van Campenhout, G. (2015). Revaluing the role of parents as financial socialization agents in youth financial literacy programs. Journal of Consumer Affairs, 49(1), 186-222.

Vitt, L. A., Anderson, C., Kent, J., Lyter, D. M., Siegenthaler, J. K., \& Ward, J.(2000). Personal finance and the rush to competence: financial literacy education in the U.S. Middleburg, VA: Fannie Mae Foundation.

Widayati, Irin, (2014). Pengaruh status sosial ekonomi orang tua, pendidikan pengelolaan keuangan keluarga, dan pembelajaran di perguruan tinggi terhadap literasi finansial mahasiswa, Jurnal Pendidikan Humaniora, 2(2), 176-183

Yushita Amanita Novi, (2017). Pentingnya Literasi Keuangan Bagi Pengelolaan Keuangan Pribadi, Jurnal Nominal, $V I(1), 11-26$ 